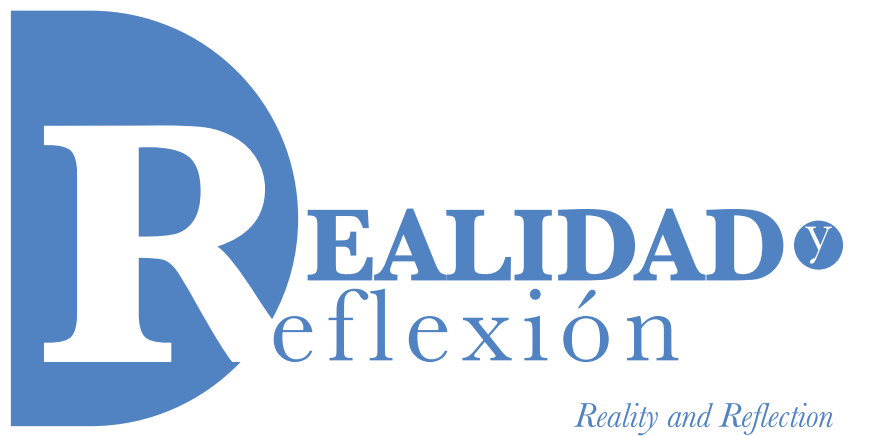

ISSN 1992-6510

e-ISSN 2520-9299

Año 18, N 47, San Salvador, El Salvador, Centroamérica. Revista Semestral Enero-Junio 2018

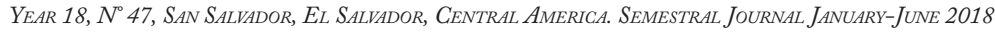

\title{
Aplicación del método de agrupamiento de grises para evaluar la eutrofización en seis humedales de Colombia
}

\author{
Application of Grey Clustering Method to assess \\ eutrophication in six freshwater Colombian wetlands \\ Brenda C. Torres-Velásquez \\ Escuela de Ciencias Naturales y Tecnología, Universidad del Turabo, Puerto Rico \\ btorres75@email.suagm.edu \\ Marlio Paredes \\ Departamento de Matemáticas, Universidad Militar Nueva Granada, Colombia \\ Instituto de Ciencia Tecnología e Innovación, Universidad Francisco Gavidia \\ Simon A. Levin Mathematical, Computational and Modeling Science Center, Arizona State University \\ Marlio.Paredes@asu.edu \\ Recibido: 16 de abril de 2018 \\ Aprobado: 30 de mayo de 2018 \\ DOI: http://dx.doi.org/10.5377/ryr.v0i47.6282
}

\section{RESUMEN}

Los humedales son recursos naturales invaluables amenazados por el exceso de nutrientes que desencadena el proceso de eutrofización. Evaluar la eutrofización es el primer paso para restaurar humedales. Una metodología para clasificar humedales por nivel de eutrofización es necesaria ya que las actuales usan índices específicos por nutrientes sin considerar su interacción. El Método de Agrupamiento de Grises (MAG) permite el uso de diferentes estándares e incluye la interacción. Usamos MAG con dos estándares (Internacional y Chino) y dos parámetros (fósforo total y nitrógreno total) para evaluar la eutrofización de seis humedales Colombianos: Tibanica, Capellanía, De Techo, La Vaca, La Conejera y Fúquene. Usando ambos estándares Laguna Fúquene clasificó como eutrófica mientras que los demás clasificaron como eutróficos bajo el estándar internacional e hipereutróficos con el estándar Chino. El análisis de orden mostró que Tibanica, Capellanía, De Techo, La Vaca y La Conejera son más eutróficos que la Laguna de Fúquene utilizando el estándar internacional.

Palabras clave: eutrofización; fósforo total; nitrógeno total; nutrientes; método de agrupación de grises; teoría de grises. 


\section{ABSTRACT}

Wetlands are invaluable natural resources, threatened by the surplus of nutrients which trigger a process known as eutrophication. Assessment of eutrophication is a first step in wetland restoration. A methodology to classify by level of eutrophication is needed as current systems use nutrient-specific indexes without consideration of nutrient interactions. The Grey Clustering Method (GCM) allows use of different standards and takes into account interaction. We used GCM and two standards (international and Chinese) and two parameters (total phosphorus and total nitrogen) to assess the eutrophication level of six freshwater Colombian wetlands: Tibanica, Capellanía, De Techo, La Vaca, La Conejera and Laguna Füquene. Using either standard, Laguna Fúquene was classified as an eutrophic wetland, while the others were classified as eutrophic using the international standard and hypertrophic using the Chinese standard. Analysis of order showed that Tibanica, Capellanía, De Techo, La Vaca, and La Conejera wetlands are more eutrophic than Laguna Fúquene using the international standard.

Keywords: eutrophication; total phosphorus; total nitrogen; nutrients; Grey Clustering Method; Grey Theory

\section{Introduction}

Wetlands are important aquatic ecosystems for human populations as well as for wildlife. Wetlands act as a form of natural infrastructure by decreasing flooding, removing pollutants from water, recharging groundwater, and protecting shorelines. Wetlands also provide a unique habitat for wildlife and serve recreational and cultural functions for humans. For example, freshwater wetlands are rich in a diverse community of benthic, limnetic and littoral invertebrates, all of them part of the food chain for waterfowl; and basin wetlands contribute to regional hydrology by recharging groundwater [1].If wetlands are lost, the cost of replacing them can be extremely expensive, if at all possible, and the loss of wetlands can result in communities having to invest more money in drinking water treatment, drainage or levee maintenance, and flood insurance.

Despite their value to society [2], wetlands are threatened by many factors, most importantly, sedimentation from neighboring urban development and addition of artificial or natural nutrients to these aquatic ecosystems from agricultural activities. An excess of nutrients can severely affect the whole ecosystem, or even destroy it, through a process known as eutrophication. The most commonly implicated nutrients, phosphate and nitrogen, come from the use of fertilizers or erosion of fields, or sewage run-off [3]. One common consequence of excessive addition of nutrients to a wetland is changes to the odor, color, turbidity, and availability of oxygen in the water that affect not only the wetland wildlife but human populations that rely on these ecosystems [2-4].

The eutrophication process begins with an increase in the population of phytoplankton and epiphytic algae that occurs as a result of the increased availability of nutrients. An increase in vegetation causes changes in water turbidity, color, odor, and availability of oxygen. The organisms eventually die and decompose resulting in a decrease in oxygen in the water [5-8]. The resultant decrease in oxygen triggers several processes including a decrease in fish, shellfish and aquatic animal populations that need oxygen dissolved in water to survive, and water treatment problems [8-10]. In summary, any change in the physical, chemical and biological characteristics of the wetland will directly impact its ecosystem [11]. 
Assessment of eutrophication is an important step in its prevention and wetland restoration, however, a methodology to classify wetlands by level of eutrophication is needed as current systems use nutrientspecific indexes without consideration of nutrient interactions. Since all nutrients and their interactions affect the composition of a wetland, an index that takes into account all nutrients involved will provide a better classification system. As phosphorus is considered the major limiting nutrient in freshwater aquatic ecosystems [3-5,12] followed by nitrogen [13-14], and high phosphate levels as well as nitrate, has been shown to enhance growth of phytoplankton in these ecosystems [3,15-16], we sought to develop an index based on these two nutrients. Interaction between these two nutrients is also taken into account, because they are both involved in several processes including photosynthesis, protein formation, and symbiotic nitrogen fixation. In addition, changes in the supply of one of these nutrients may affect the other such that it limits the productivity in wetlands [18]. For example, a surplus of phosphorus in certain wetlands leads to nitrogen scarcity making it the limiting nutrient [19-20]. In the example of photosynthesis, a low phosphorus concentration is associated with a less photosynthetic capacity-related to concentration of total nitrogen within the leaf [17]. Furthermore, many studies have shown that a high nitrogen to phosphate $(\mathrm{N}: \mathrm{P})$ ratio is associated with an increase in phytoplankton populations [14,21] while a low $\mathrm{N}: \mathrm{P}$ ratio favors cyanobacteria growth [20,22-23]

\section{Grey System Theory}

Grey System Theory (GST) was developed in 1982 to study systems where available information is insufficient and/or there is a great deal of uncertainty in the data [24-26]. GST has been used in industry, agriculture, economics, energy, transportation, geography, geology, meteorology, hydraulic power, ecology, environment studies, medicine, education, military science, finance, life sciences, and information systems research [27]. Put simply, GST is a type of analysis that takes complete known (white) and unknown information (black) about a specific phenomenon, and finds a solution in levels of grey.

\section{Grey Clustering Method}

The Grey Clustering Method (GCM) is part of GST and consists of an iterative algorithm for classification of $n$-objects into one of $s$-classifications, combining $m$-parameters measures of each object. This method assumes that there are n-cluster objects, m-cluster indexes and $s$-different grey classifications. Data for objects are presented in a matrix $X$ with dimension $m \times n$, where $x_{j i}$ is the $j$-th parameter value for the $i$-th object of data matrix, and where $j=1, \ldots, m$ and $i=1, \ldots, n$. A matrix with standards by category is used and is known as matrix $S$; this matrix has a dimension of $m \times s$, and its elements are $\lambda_{j k}$,where $k=1, \ldots, s$. One standard application of the GCM is the Chinese classification of wetlands (i.e., the objects) into six levels or categories of eutrophication: (1) oligotrophic, (2) lower-mesotrophic, (3) mesotrophic, (4) upper-mesotrophic, (5) eutrophic and (6) hypereutrophic. The Chinese standard used 
four chemical parameters including chlorophyll, chemical oxygen demand, total phosphorus, and total nitrogen [28]. This standard can accurately classify objects and calculate indexes to determine object ordering when two or more objects are in the same category [29].

\section{Materials and Methods}

\section{Study Data}

Public data from Colombia that describes six freshwater wetlands: Tibanica (LT), Capellanía (LC), De Techo (LDT), La Vaca (LLV), La Conejera (LLC), and Laguna Fúquene were used to conduct this study. Data collected from official reports represents the most current state of the six wetlands. Parameters used were total phosphorus (TP) and total nitrogen (TN). The average concentration of each parameter per wetland was calculated, using data available for the monitoring stations.

The six freshwater wetlands evaluated in this study are located in the Cundiboyacense tableland, Laguna Fúquene is located $80 \mathrm{~km}$ far from Bogotá and the other five wetlands are part of the Principal Ecologic Structure (known by acronym, EPP which stands for Estructura Ecológica Principal) of Bogotá, and as such, they are protected ecosystems [31]. Sabana de Bogotá complex of wetlands together with the Cundiboyacense wetlands form a region that is one of the most biodiverse regions in the world [30]. Despite the fact that this region has a rich and distinctive avifauna, these wetlands are highly affected by pollutants mostly from agricultural activities and new urbanization [32]. Because of this, the EPP is developing plans to restore these wetlands.

\section{Tibanica Wetland}

Tibanica Wetland (TW) is a freshwater wetland located in the basin of the Tunjuelito River, in the flat part of Bogotá River (latitude 436'10.58”N, longitude $\left.74^{\circ} 12^{\prime} 15.88^{\prime \prime} \mathrm{W}\right)$. The area of TW is 28.8 hectares, and is limited by the South Highway to the west and Bogotá municipality of Soacha to the southwest [33]. Important factors that have caused eutrophication of TW are the discharge of wastewater into the wetland and the local burning of wood to obtain charcoal.

\section{De Techo Wetland}

De Techo (DTW) is a freshwater wetland located within the Bogotá city limits in the Kennedy region (latitude 4 38 '52.72”N, longitude $74^{\circ} 8{ }^{\prime} 35.32^{\prime \prime} \mathrm{W}$ ) and it has an area of 11.67 hectares. Main factors that have caused eutrophication and a loss in biodiversity in DTW are the invasion of a foreign plant (cattails) and new urban settlements that have split DTW into three separate sections [34].

\section{Capellania Wetland}

Capellanía $(\mathrm{CW})$ is a freshwater plain wetland located in the southwest urban area of Fontibón, Bogotá (latitude $4^{\circ} 40^{\prime} \mathrm{N}$ and longitude $74^{\circ} 07^{\prime} \mathrm{W}$ ); the total area is 27 hectares. LC is isolated from all the other components of the EEP but due to its acceptable water quality, richness in flora and fauna, and community support, $\mathrm{CW}$ has been included in the Sistema Distrital de Ambiente plans for EEP recuperation [31]. Presence of livestock and street pets that act as predators, and the building of roads and motorways, are the main factors that affect this wetland [35]. 


\section{La Vaca Wetland}

La Vaca (LVW) is a freshwater wetland located southwest of Bogotá city in the Kennedy region (latitude $4^{\circ} 63^{\prime} \mathrm{N}$ and longitude $74^{\circ} 1^{\prime} \mathrm{W}$ ); it has an area of 7.98 hectares. It is divided into two independent sectors separated by a densely populated, urban area. Main elements that have affected LVW are the presence of other competitive fauna species (e.g., dogs, cats, chamón bird); grazing activities; high volume of urban and industrial waste deposition; discharge of sewage; and intentional wood burning [36].

\section{La Conejera Wetland}

La Conejera (LCW) is a freshwater wetland with 58.89 hectares of area, located between latitude $4^{\circ} 45^{\prime} \mathrm{N}$ and longitude $74^{\circ} 6^{\prime} \mathrm{W}$ in the savanna of Bogotá [30]. LCW belongs to the Capital District of Colombia and it has gotten a lot of attention due to the richness of endemic vegetation and species, some of which is endangered. Main factors leading to eutrophication in LCW has been the discharge of residual wastewater containing high levels of organic matter and sediments into the wetland and displacement of endemic species to other ecosystems [37].

\section{Laguna Fúquene}

Laguna Fúquene (LF) is a freshwater wetland with 3000 hectares of area located on the western side of the eastern range of the Colombian Andes (latitude $5^{\circ} 28^{\prime} 12^{\prime} \mathrm{N}$, longitude $73^{\circ} 44^{\prime} 14^{\prime \prime} \mathrm{W}$ ) [38-39]. Main factors leading to eutrophication in LF include the drainage of marshes, intensive deforestation, farming and cattle pastures expansion along its shores, and discharge of sediments and nutrients into LF [38].

\section{Lake Trophic Classification}

The trophic state of lakes is classified by ecosystem productivity and divided into six categories from a simple oligotrophic lake to lower mesotrophic, mesotrophic, upper mesotrophic, eutrophic, and hypereutrophic lakes. This classification system varies according to the environmental standards of a country or region [40]. Differences between trophic categories can be very subtle. For example, differences in chlorophyll levels [28] are set at $1.0 \mathrm{mg} / \mathrm{L}$ in oligotrophic lakes to $2.0 \mathrm{mg} / \mathrm{L}$ in lower mesotrophic in some systems, and $1.7 \mathrm{mg} / \mathrm{m}^{3}$ and $4.7 \mathrm{mg} / \mathrm{m}^{3}$, respectively in others [3]. Each category, used to in our analysis, is described below.

\section{Oligotrophic state}

An oligotrophic state is characterized for low concentration of nutrients and biomass, high water clarity, and deep photic zones. Oligotrophic lakes can, in some cases, support a cold-water fishery [41-42]. They are usually very transparent and have abundant hypolimnetic oxygen if stratified [43]. If there is a low release of phosphorus from sediments, oligotrophic lakes are usually stable [6].

\section{Mesotrophic state}

A mesotrophic state is characterized by a moderate concentration of nutrients and a moderate level of productivity. Mesotrophic lakes have moderate fertility in terms of its algal biomass [44]. 


\section{Eutrophic state}

An eutrophic state is characterized by a nutrient rich lake that is very fertile in terms of algal biomass. Fertility occurs due to nutrients entering into the aquatic ecosystem from the surrounding land or recycled sediments $[6,44]$.

\section{Parameters and Data}

Two standards for eutrophication were used in our analysis: the international standard [3] and the Chinese standard [28]. The international standard uses three categories for classifying trophic states: oligotrophic, mesotrophic and eutrophic (Table1). The Chinese standard uses six categories: oligotrophic, lower mesotrophic, mesotrophic, upper mesotrophic, eutrophic, and hypereutrophic (Table 2).

Data about the wetlands used in the analysis was collected through a literature research. To study the trophic level of the five wetlands of the
Sabana de Bogotá (Laguna Tibanica, Capellanía, De Techo, La Conejera and La Vaca), official reports from Colombia Government were used [30-31,33-38,45-49]. Descriptive data about Laguna Fúquene was obtained from a recent Master Thesis by Montenegro-Paredes [38].

The two parameters used to assess eutrophication, TP and TN, were both measured in milligram (mg) per liter (L). Data analysis and development of algorithm was implemented in Matlab.

Table 1 shows the concentration of TP and TN that define a wetland into one of three following trophic levels: oligotrophic, mesotrophic or eutrophic.

Table 2 shows the standards used to classify wetlands in China, and the concentration of TP and TN used to classify a wetland into six categories: oligotrophic, low mesotrophic, mesotrophic, upper mesotrophic, eutrophic or hypereutrophic.

\section{Table 1}

Trophic international standard

\begin{tabular}{|c|c|c|c|}
\hline \multirow{2}{*}{$\begin{array}{c}\text { Evaluation Index } \\
(\mathbf{m g} / \mathbf{L})\end{array}$} & \multicolumn{3}{|c|}{ Trophic Categories } \\
\cline { 2 - 4 } & Oligotrophic & Mesotrophic & Eutrophic \\
\hline TP & 0.008 & 0.0267 & 0.084 \\
\hline TN & 0.661 & 0.753 & 1.875 \\
\hline
\end{tabular}

Note: TP: total phosphorus; TN: total nitrogen. Source: Wetzel RG. 2001 
Table 2

Chinese eutrophication standard

\begin{tabular}{|c|c|c|c|c|c|c|}
\hline \multirow{2}{*}{$\begin{array}{c}\text { Evaluation } \\
\text { Index }(\mathbf{m g} / \mathbf{L})\end{array}$} & \multicolumn{7}{|c|}{ Trophic Categories } \\
\cline { 2 - 7 } & $\mathbf{O}$ & LM & $\mathbf{M}$ & UM & $\mathbf{E}$ & HE \\
\hline TP & 0.003 & 0.005 & 0.025 & 0.050 & 0.200 & 0.600 \\
\hline TN & 0.030 & 0.050 & 0.300 & 0.500 & 2.000 & 6.000 \\
\hline
\end{tabular}

Note: O: Oligotrophic; LM: Lower Mesotrophic; M: Mesotrophic; UM: Upper Mesotrophic; E: Eutrophic; HE: Hypereutrophic. Source: Zhou L and Xu S. 2006

In table 3, the average $\mathrm{TP}$ and $\mathrm{TN}$ by wetland value for each wetland according to public is displayed. Values represent the most current databases and published literature.

\section{Table 3}

Total phosphorus and total nitrogen for six selected Colombian wetlands

\begin{tabular}{|c|c|c|c|c|c|c|}
\hline $\begin{array}{c}\text { Parameters } \\
(\mathbf{m g} / \mathrm{L}) / \\
\text { Wetlands }\end{array}$ & TW & DTW & CW & LVW & LCW & LF \\
\hline TP & 28.12 & 1.69 & 1.9 & 3.67 & 3.93 & 0.08 \\
\hline TN & 19.78 & 7.35 & 15.7 & 29 & 17.03 & 1.73 \\
\hline
\end{tabular}

Note: TP: total phosphorus; TN: total nitrogen; TW; Tibanica Wetland; DTW: De Techo Wetland; CW: Capellanía Wetland; LVW: La Vaca Wetland; LC: La Conejera Wetland; LF: Laguna Fúquene. Source: Authors

\section{Grey Clustering Method}

The GCM consists of five steps to classify an object(s) into the groups defined. These steps are: 1) take out the dimension of the dataset; 2) use the whitenization function; which uses known data to prepare incomplete data to be classified; 3) calculate the matrix of the weights; 4) calculate the clustering vector; and 5) determine the incidence degree value, also referred to as the Grey Score (GS). The GS has two main functions: to assign each object to the corresponding category and give an order to the relationship when two objects are classified in the same category. Steps for the evaluation of eutrophication of wetlands are described as follows:

1. Change the dimensional data into nondimensional data, for both the dataset of 
objects to be classified and the dataset of standards. To change the dimensional matrix $S=\left(\lambda_{i j}\right) \quad$ (eutrophication standards) and $X=\left(x_{i j}\right) \quad$ (data), the average standard value method was used. This method calculates the average by row of a matrix - named correction factor $\mathrm{CF}_{j}$ - and then divides each value of same matrix by the corresponding average. Calculation is as follows;

Correction factor:

$$
C F j=\frac{\sum_{k=1}^{s} \lambda_{j k}}{S}
$$

for each $\mathrm{j}$, where $j=1, \ldots, m$.

$$
\lambda_{j k}=\frac{\lambda_{j k}}{C F_{j}}
$$

for each $j$, where $j=1, \ldots, \mathrm{m}$; note that we are calling again $\lambda_{j k}$ the elements of $S$ matrix.

Transforming $\chi$ matrix

$$
\chi_{j i}=\frac{\chi_{j i}}{C F_{j}}
$$

for each $j$, where $j=1, \ldots, m$.

2. Apply the whitenization weight function $f_{j}^{k}$, where $f_{j}^{k}$ is the function applied to the jth index or parameter attributed to the $k_{t h}$ grey classification. Whitenization weight function (WWF) of the $j_{\text {th }}$ pollutant to the kth classification is denoted as $f_{j}^{k}\left(x_{i j}\right)$. When the eutrophication level increase if the measure of parameter increase, WWF is defined as follow:

$$
\begin{aligned}
f_{j}^{1}(x) & = \begin{cases}1 & , x \in\left[0, \lambda_{j 1}\right] \\
\frac{\lambda_{j 2}-x}{\lambda_{j 2}-\lambda_{j 1}} & , x \in\left(\lambda_{j 1}, \lambda_{j 2}\right) \\
0 & , x \in\left[\lambda_{j 2}, \infty\right)\end{cases} \\
f_{j}^{k}(x) & = \begin{cases}\frac{x-\lambda_{j(k-1)}}{\lambda_{j k}-\lambda_{j(k-1)}} & , x \in\left(\lambda_{j(k-1)}, \lambda_{j k}\right] \\
\frac{\lambda_{j(k+1)}-x}{\lambda_{j(k+1)}-\lambda_{j k}^{k}} & , x \in\left(\lambda_{j k}, \lambda_{j, k+1}\right) \\
0 & , x \in\left[0, \lambda_{j(k-1)}\right] \cup\left[\lambda_{j(k+1)}, \infty\right)\end{cases}
\end{aligned}
$$

$$
f_{j}^{s}(x)= \begin{cases}\frac{x-\lambda_{j(s-1)}}{\lambda_{j s}-\lambda_{j(s-1)}} & , x \in\left(\lambda_{j(s-1)}, \lambda_{j s}\right) \\ 1 & , x \in\left[\lambda_{j s}, \infty\right) \\ 0 & , x \in\left[0, \lambda_{j s}\right]\end{cases}
$$

(3) Calculate $\eta_{j}^{k}$, matrix of cluster weight, where $j_{t h}$ is the index attributed to the $k_{t h}$ grey classification.

Suppose that $\lambda_{j, k}$ is the threshold of $k$ subclass of $j$ index, then $\eta_{j}^{k}$ calculation is as follow:

$$
\eta_{j}^{k}=\frac{1 / \lambda_{j k}}{\sum_{j=1}^{m} 1 / \lambda_{j k}}, \text { where } k=1, \ldots, s
$$

(4) Calculate the clustering vector $\sigma_{i}^{k}$ which is defined as:

$\sigma_{i}^{k}=\sum_{j=1}^{m} f_{j}^{k}\left(x_{i j}\right) * \eta_{j}^{k}$, where $i=1, \ldots$, and $k=1, \ldots S$

(5) Determine the incidence degree value (grey score), to classify objects in grey classes. 
According to the most subjection principle, incidence degree value is determined as $\sigma_{i}^{k^{*}}=\max _{1 \leq k \leq s}\left\{\sigma_{i}^{k}\right\}$, where this value represents the allocation of an object to the grey class $k^{*}$.

Ordering Objects Within a Category Using GCM

In GCM, the final stage of algorithm provides the incidence degree value (grey score) for each object. Then, two sceneries can happen: that all objects are classified in different categories, or that two or more elements are classified at same category. In the second scenery, the grey score also provides the relationship order among the elements classified in same cluster. Ordering is provided in an ascending numeric scale within a specific category from less-to-more, e.g. less mesotrophic to more mesotrophic.

\section{Results}

Table 4 presents a matrix with the result of clustering vectors for each wetland. Incidence degree is determined using the most subjection principle that states that the incidence degree (also known as grey score) is the highest punctuation that each wetland obtains. This score is located in a category that is the final result of classification of the wetland. For example, for Tibanica, the highest value is 1 , and it lies in the category of eutrophic. Then, Tibanica is classified according its concentrations of phosphorus and nitrogen as an eutrophic wetland with a GS of 1 .

\section{Table 4}

Incidence degree values using Grey Clustering Method with international standard

\begin{tabular}{|c|c|c|c|}
\hline Wetlands & Oligotrophic & Mesotrophic & Eutrophic \\
\hline Tibanica & 0 & 0 & 1 \\
\hline De Techo & 0 & 0 & 1 \\
\hline Capellanía & 0 & 0 & 1 \\
\hline La Vaca & 0 & 0 & 1 \\
\hline La Conejera & 0 & 0 & 1 \\
\hline Fúquene & 0 & 0.102 & $\mathbf{0 . 8 9 4}$ \\
\hline
\end{tabular}

Source: Authors

Table 5

Incidence Degree Values using Grey Clustering Method with Chinese standard

\begin{tabular}{|c|c|c|c|c|c|c|}
\hline Wetlands & O & LM & M & UM & E & HE \\
\hline Tibanica & 0 & 0 & 0 & 0 & 0 & 2 \\
\hline De Techo & 0 & 0 & 0 & 0 & 0 & 2 \\
\hline Capellanía & 0 & 0 & 0 & 0 & 0 & 2 \\
\hline
\end{tabular}




\begin{tabular}{|c|c|c|c|c|c|c|}
\hline Wetlands & O & LM & M & UM & E & HE \\
\hline La Vaca & 0 & 0 & 0 & 0 & 0 & 2 \\
\hline La Conejera & 0 & 0 & 0 & 0 & 0 & 2 \\
\hline Fúquene & 0 & 0 & 0 & 0.489 & $\mathbf{0 . 5 1 1}$ & 0 \\
\hline
\end{tabular}

Source: Authors

Table 5 presents results for the six wetlands using the Chinese standard. Table 6 summarizes Tables 4 and 5, presenting the GS for each wetland for each standard.

\section{Table 6}

Results of Grey Clustering Method Algorithm Assessment of Six Colombian Wetlands Colombia by standard

\begin{tabular}{|c|c|c|c|c|}
\hline \multirow{2}{*}{ Wetlands } & \multicolumn{2}{|c|}{ International standard } & \multicolumn{2}{c|}{ Chinese standard } \\
\cline { 2 - 5 } & Classification & Grey Score & Classification & Grey Score \\
\hline Tibanica & Eutrophic & 1 & Hypereutrophic & 2 \\
\hline De Techo & Eutrophic & 1 & Hypereutrophic & 2 \\
\hline Capellanía & Eutrophic & 1 & Hypereutrophic & 2 \\
\hline La Vaca & Eutrophic & 1 & Hypereutrophic & 2 \\
\hline La Conejera & Eutrophic & 1 & Eutrophic & 0.5 \\
\hline Fúquene & Eutrophic & 0.9 & & \\
\hline
\end{tabular}

\section{Discussion of results and conclusions}

We sought to classify six freshwater Colombian wetlands into trophic states using two standards and two parameters. It is interesting that even though the cut-offs for the eutrophic category are different in two standards, Laguna Fúquene is classified as a eutrophic wetland under both standards. However, there were two different Grey Scores (Table 6). In fact, using the Chinese standard, the Laguna Fúquene Grey Score decreased to 0.5. Since the Chinese standard has more categories for classification of wetlands than the international standard, differences in the Grey Score were expected.
Using the international standard, all of the wetlands including Laguna Fúquene were classified as eutrophic. However, Laguna Fúquene was 0.1 points less eutrophic than Tibanica, Capellanía, La Conejera, La Vaca, and De Techo wetlands (Table 6). This means that Tibanica, Capellanía, La Conejera, La Vaca, and De Techo wetlands are affected to the same extent by the excess of nutrients in the water. The homogeneity of results was replicated when the Chinese standard of eutrophication was used to assess these wetlands. However, using the Chinese standard, they were all classified as hypereutrophic (same period, same data) and had a Grey Score of 2. The same classification result for the wetlands of the Capital District 
may be explained by the fact that they are located in close proximity to each other in the same geographic zone. Other have suggested that as many of them are tributaries of other bodies of water, anything that happens to one of these wetlands will eventually affect the others. This may start with the migration of endemic species and evolve into changes in the trophic state as nutrients are transported through the water.

\section{Grey Clustering as assessment technique}

The GCM as an assessment technique is widely used today, mainly because of the accuracy of its results and ease in which the basic principles of GCM can be adapted to the data available. This method showed that its interactive structure allows for the analysis of a whole set of parameters chosen by researcher at the same time, without minimizing any of them. In addition, researchers can obtain a valid classification of objects in the study.

A very important component on this analysis is the use of reference standards, chosen by the researcher, to classify objects into a tropic state. As standards change between countries or areas, the incidence degree changes too, potentially assigning objects into a completely different category. Change in trophic classification can also happen if new parameters are included in the analysis (e.g., dissolved oxygen). This is an advantage to this methodology in that it allows the researcher to improve their results by adding new parameters as soon as they have more and/ or new data to analyze.

Finally, the incidence degree value not only allows a wetland to be categorized by trophic state, but it also allows the researcher to determine an order to the relationship among all the wetlands that were classified in the same category. For example, using the Chinese standard to assess eutrophication, Tibanica, Capellanía, La Conejera, La Vaca, and De Techo wetlands were all classified as hypereutrophic with a GS of 2. As all the five wetlands obtained the same score, we can say that within the hypereutrophic category, they are all at the same level of eutrophication. When we used the international standard, and equivalent result was obtained regarding relationship order, that is, all five wetlands obtained the same GS within the eutrophic category and they were therefore at the same level of eutrophication.

\section{Acknowledgments}

The first author would like to express her gratitude to Dr. Kay Tomashek for her mentoring and guidance. Both authors would like to thank Dr. Kay Tomashek for her help reviewing this manuscript.

\section{References}

[1] Smith, R.L. and Smith, T.M. Wetlands, in Elements of Ecology. 8th edition, San Francisco, California, Pearson Education, 2012

[2] Mitsch, W.J. and Gosselink J.G., Wetlands. $4^{\text {th }}$ edition, New Jersey: John Wiley and Sons, 2007.

[3] Wetzel, R.G., Limnology: Lake and River Ecosystems. ${ }^{3 r d}$ edition, Oxford, UK: Academic Press Elsevier, 2001.

[4] Reddy, K.R., D‘Angelo E.M., and Harris 
W.G., Biochemistry of Wetlands, in Handbook of Soil Sciences, edited by Malcom E. Summer, CRC Press, 2000, pp. G89-G114.

[5] Correll, D.L., Phosphorus: A rate limiting nutrient in surface waters. Poultry Science, 78(5), pp. 674-682, 1999. http://dx.doi.org/10.1093/ ps/78.5.674

[6] Carpenter, S.R., Eutrophication of aquatic ecosystems: Bistability and soil phosphorus, Proceedings of the National Academy of Sciences of the United States of America (PNAS), 102(29), pp. 10002-10005, 2005. http://dx.doi.org/10.1073/pnas.0503959102

[7] Lovelock C.E., Ball M.C., Martin K.C., and Feller I. C., Nutrient Enrichment Increases Mortality of Mangroves. PLoS ONE, 4(5): e5600, 2009. http://dx.doi.org/10.1371/journal. pone. 0005600

[8] Abid, A.A., Sarvejeet, S.G. and Khan, F.A. Eutrophication: Threat to Aquatic Ecosystems, in Eutrophication: Causes, consequences and Control, edited by Ansari, A.A., Sarvajeet, S.G., Lanza, G.R. and Rast, W. Springer Netherlands, 2011, pp. 143-170. http://dx/doi. org/10.1007/978-90-481-9625-8_7

[9] Environmental Protection Agency (EPA), Protecting natural wetlands, A guide to stormwater best management practices. EPA843-B-96-001.

[10] NCSU Water Quality Group. Wetland loss and degradation. [Online]. [date of reference June 10 $\left.{ }^{\text {th }}, 2016\right]$. Available at: http://www.water.ncsu. edu/watershedss/info/wetlands/wetloss.html
[11] Bressler, D. and Paul, M., Effects of eutrophication on wetland ecosystems [Online]. [date of reference June 10th 2016]. Available at: https://www.researchgate.net/ profile/David_Bressler/publication/252291163_ EFFECTS_OF_EUTROPHICATION_ON_ WETLAND_ECOSYSTEMS/links/551ed2860cf29dcabb083b03.pdf

[12] Correll, D.L. The Role of Phosphorus in the Eutrophication of Receiving Waters: A Review, Journal of Environmental Quality, 27, pp. 261-266, 1998. http://dx.doi.org/10.2134/ jeq1998.00472425002700020004x

[13] Vitousek, P.M. and Howarth, R.W. Nitrogen limitation on land and in the sea: how can it occur?, Biochemistry, 13, pp. 87-115, 1991. http://dx.doi.org/10.1007/BF00002772

[14] Smith ,V.H. Effects of nitrogen:phosphorus supply ratios on nitrogen fixation in agricultural and pastoral ecosystems. Biogeochemistry, 18, pp. 19-35, 1992. http://dx.doi.org/10.1007/ BF00000424

[15] Schindler, D.W. Eutrophication and recovery in experimental lakes, Sciences, 184(4139), pp. 897-899, 1974. http://dx.doi. org/10.1126/science.184.4139.897

[16] Smith, V.H., Tilman G.D. and Nekola J.C. Eutrophication: impacts of excess nutrient inputs on freshwater, marine, and terrestrial ecosystems, Environmental Pollution, 100(1-3), pp. 179-196, 1999. http://dx.doi.org/10.1016/ S0269-7491(99)00091-3

[17] Reich P.N., Oleksyn J. and Wright I.J. 
Leaf phosphorus influences the photosynthesisnitrogen relation: a cross-biome analysis of 314 species, Oecologia, 160 (2), pp. 207-212, 2009. http://dx.doi.org/10.1007/S00442-009-1291-3

[18] Doering P.H., Oviatt C.A., Nowicki B.L., Klos E.G. and Reed L.W. Phosphorus and nitrogen limitation of primary production in a simulated estuarine gradient, Marine Ecology Progress Series, 124, pp. 271-287, 1995. http:// dx.doi.org/10.3354/meps 124271

[19] Havens, K.E. Secondary nitrogen limitation in a subtropical lake impacted by non-point source agricultural pollution. Environmental pollution, 89(3), pp. 241-246, 1995. http:// dx.doi.org/10.1016/0269-7491(94)00076-P

[20] Havens K.E., James R.T., East T.L and Smith V.H. N:P ratios, light limitation, and cyanobacterial dominance in a subtropical lake impacted by non-point source nutrient pollution, Environmental Pollution, 122(3), pp.379-390, 2003. http://dx.doi.org/10.1016/ S0269-7491(02)00304-4

[21] Smith, V.H. and Bennet S.J. Nitrogen:phosphorus supply ratios and phytoplankton community structure in lakes, Archiv für Hydrobiologie [Online] 146, pp. 37-53. 1999. [date of reference June 10th, of 2016]. Available at: http://cat.inist. $\mathrm{fr} /$ ?aModele $=$ afficheN\&cpsidt $=1955816$

[22] Smith V.H. Low nitrogen to phosphorus ratios favor dominance by blue-green algae in lake phytoplankton, Science, 221(4611), pp. 669-671, 1983. http://dx.doi.org/10.1126/ science.221.4611.669
[23] Ferber L.R., Levine S.N., Lini A. and Livingston G.P. Do cyanobacteria dominate in eutrophic lakes because they fix atmospheric nitrogen?, Freshwater Biology 49(6), pp. 690708, 2004. http://dx.doi.org/10.1111/j.13652427.2004.01218.x

[24] Julong, D. Introduction to Grey System Theory, The Journal of Grey systems [Online]. 1 (1), pp.1-24, 1989. [date of reference June 10th of 2016]. Available at: http://citeseerx.ist.psu.edu/ viewdoc/download?doi=10.1.1.678.3477\&re$\mathrm{p}=\mathrm{rep} 1 \&$ type $=\mathrm{pdf}$

[25]Huang, J.C. The key factor of the internet information technology on the quality of life for the elderly: application of grey system theory. eNewsletter 33 [Online]. 33, 2010. [date of reference June 10th of 2016]. Available at: http:// ieeesmc.org/newsletters/back/2010_12/main_ article2.html

[26] Slavek, N. and Jovic ,A. Application of Grey System Theory to Software Projects Ranking, Automatika, [Online], 53(3), pp. 284-293, 2012. [date of reference June $10^{\text {th }}$ of 2016]. Available at: https://automatika.korema.hr/index.php/automatika/article/view/80

[27] Lin Y. and Liu S. A historical introduction to grey systems theory, Systems, Man and $\mathrm{Cy}^{-}$ bernetics 2004 IEEE International Conference, 3, pp. 2403-2408. http://dx.doi.org/10.1109/ ICSMC.2004.1400689

[28] Zhou, L. and Xu S. Application of Grey Clustering Method in Eutrophication Assessment of wetland, Journal of American Science, [Online], 2(4), pp. 52-57, 2006. [date of referen- 
ce June 10th of 2016]. Available at: http://www. sciencepub.net/american/0204/09-0204-zhoulinfei-am.pdf

[29] Liping W., Kunrong L. and Weibo Z. 2011. Application of Grey Clustering Method for Water Quality Evaluation in Fenchuan River Yan'an Baota Area, Water Resource and Environmental Protection (ISWREP), 2011 International Symposium, 2, pp. 838-841. http://dx.doi. org/10.1109/ISWREP.2011.5893142

[30] Empresa de Acueducto y Alcantarillado de Bogotá and Fundación Humedal La Conejera (EAAB-FHLC a). Plan de Manejo Ambiental Humedal La Conejera. Colombia: Secretaría Distrital de Ambiente [Online]. [date of reference December 23rd 2015]. Available at: http:// ambientebogota.gov.co/c/document_library/ get_file?uuid=115426b5-4dd2-4c92-a772-fc1784fe0d2b\&groupId=3564131

[31] Empresa de Acueducto y Alcantarillado de Bogotá and Conservación Internacional Colombia (EAAB-CIC a) [Online]. Preámbulo [date of reference December 23 ${ }^{\text {th }}$ 2015]. Available at: http://ambientebogota.gov.co/ documents/10157/25031245-16ba-46b3-bd514b5518916afa

[32] Rosselli L, and Stiles G. Wetlands habitats of the Sabana de Bogotá Andean Highland Plateau and their birds, Aquatic Conservation: $\mathrm{Ma}-$ rine and freshwater ecosystems, 22(3), pp. 303317, 2012. http://dx.doi.org/10.1002/aqc.2234

[33] Secretaría Distrital de Ambiente (SDA b). Plan de Manejo Ambiental del Parque Ecológico Distrital Humedal Tibanica. Aspectos generales
Colombia [Online]. [date of reference December 23th 2015]. Available at: http:// http://ambientebogota.gov.co/documents/10157/74c58c25e4d2-49d3-a662-141ac6cf745e

[34] Empresa de Acueducto y Alcantarillado de Bogotá and Pontificia Universidad Javeriana (EAAB-PUJ b). Plan de Manejo Ambiental del Humedal De Techo, Bogotá, Colombia: Secretaría Distrital de Ambiente [Online]. [date of reference December 23th 2015]. Available at: http://ambientebogota.gov. $\mathrm{co} / \mathrm{c} /$ document_library/get_file?uuid $=8 \mathrm{~d} 20 \mathrm{~b}$ de8-3f09-4c0f-aaf4-696350f4aef4\&groupId $=10157$

[35] Empresa de Acueducto y Alcantarillado de Bogotá and Conservación Internacional Colombia (EAAB-CIC c). Plan de Manejo Ambiental Humedal Capellanía.Evaluaci冈ón y problemática ambiental, Colombia [Online]. [date of reference December 23th 2015]. Available at: http:// ambientebogota.gov.co/documents/10157/2bcac974-f283-42a3-bf30-9d226ae693f7

[36] Empresa de Acueducto y Alcantarillado de Bogotá and Pontificia Universidad Javeriana (EAAB-PUJ a). Plan de Manejo Ambiental del Humedal de La Vaca, Bogotá, Colombia, Secretaría Distrital de Ambiente [Online]. [date of reference December 23th 2015]. Available at: http://ambientebogota.gov.co/documents/10157/40b5fd17-9d0f-4bd8-8ef8-1ccc6d9de603

[37] Empresa de Acueducto y Alcantarillado de Bogotá and Fundación Humedal La Conejera (EAAB-FHLC b). Plan de Manejo Ambiental Humedal La Conejera, Plan de Acción. Colom- 
bia: Secretaría Distrital de Ambiente [Online]. [date of reference December 23th 2015]. Available at: http://ambientebogota.gov.co/c/document_library/get_file?uuid=6b2daa19-886e-4ae 5-8a13-026660620f47\&groupId=3564131

[38] Montenegro-Paredes M.I. Modelling of wetland habitat availability and distribution under management alternatives. A case study of the Fúquene Lake, Colombia. Msc. Thesis, International Institute for Geo-Information Science and Earth Observation (ITC), Enschede, The Netherlands, 2004.

[39] Yagüe J. Multitemporal remote sensing of the outburst of three aquatic weeds in the Fúquene Lagoon, Colombia, International Workshop on the Analysis of multi-temporal remote sensing images, pp. 44-48, 2005. http://dx.doi. org/10.1109/AMTRSI.2005.1469837

[40] Dodds W.K. Trophic State and Eutrophication in Freshwater Ecology: Concepts and Environmental Applications, 1st edition. London, UK: Academic Press Elsevier. 2002.

[41] Dodds W.K., Jones J.R. and Welch E.B. Suggested classification of stream trophic state: distributions of temperature stream types by chlorophyll, total nitrogen and phosphorus, Water research [Online]. 32(5), pp. 14551462, 1998. [date of reference June 10th of 2016]. Available at: https://www.owrb.ok.gov/ quality/standards/pdf_standards/scenicrivers/ Dodds\%20Jones\%20Welch\%201998.PDF

[42] Carpenter S.R., Ludwig D. and Brock W.A. Management of eutrophication for lakes subject to potentially irreversible change, Ecological
Applications, 9(3),751-771, 1999. http://dx.doi. org/10.1890/1051-0761(1999)009[0751:MOEFLS]2.0.CO;2

[43] [WOW] Water on the web. Glossary [Online]. [date of reference October 4th of 2015]. Available at: http://www.waterontheweb.org/ aboutus/index.html

[44] RBM Environmental Laboratories Inc. Lake trophic states [Online]. [date of reference October 4th of 2015]. Available at: http://rmbel. info/lake-trophic-states-2/

[45] Empresa de Acueducto y Alcantarillado de Bogotá and Conservación Internacional Colombia [EAAB-CIC b]. Plan de Manejo Ambiental Humedal Capellanía. Componente Ecológico, Colombia [Online]. [date of reference December 23th 2015]. Available at: http://ambientebogota.gov.co/documents/10157/fe198843-58cf4482-aaf7-f2e93f8ecead

[46] Secretaría Distrital de Ambiente. (SDA a), Colombia [Online]. [date of reference December 23th 2015]. Available at: http://ambientebogota.gov.co/humedales.

[47] Secretaría Distrital de Ambiente (SDA c). Plan de Manejo Ambiental del Parque Ecológico Distrital Humedal Tibanica, Componente físico, Colombia [Online]. [date of reference December 23th 2015]. Available at: http://ambientebogota.gov.co/documents/10157/4edf22f4-b802-401a-ae91-dc7a70c8a2e9

[48] Secretaría Distrital de Ambiente (SDA d). Plan de Manejo Ambiental del Parque Ecológico Distrital Humedal Tibanica, Componente 
ecológico, Colombia [Online]. [date of reference December 23th 2015]. Available at: http:// ambientebogota.gov.co/documents/10157/5d41fa80-fde8-4a9a-8a40-86905a4866ae

[49] Secretaría Distrital de Ambiente.(SDA e). Plan de Manejo Ambiental del Parque Ecológico Distrital Humedal Tibanica, Problemática ambiental, Colombia [Online]. [date of reference December 23th 2015]. Available at: http:// ambientebogota.gov.co/documents/10157/ 3f9f9c95-b2f2-4e08-8b12-9dc78391b520 